\title{
THE SIXTH SYMPOSIUM IN APPLIED MATHEMATICS
}

The Sixth Symposium in Applied Mathematics of the American Mathematical Society was held at Santa Monica City College, Santa Monica, California, on August 26-28, 1953. The topic of the Symposium was Numerical analysis, and it was co-sponsored by the National Bureau of Standards. The following 185 persons, including 107 members of the Society, attended:

A. A. Albert, O. W. Albert, F. L. Alt, L. H. Amaya, F. R. Anderson, M. M. Andrew, L. A. Aroian, K. L. Austin, W. S. Bagby, T. Bauer, E. F. Beckenbach, M. M. Beenken, F. Bell, J. C. Bell, J. L. Bell, Stefan Bergman, E. J. Betinis, N. M. Blachman, J. Brandstatter, Paul Brock, L. F. Brown, R. H. Bruck, G. Bullock, K. A. Bush, A. S. Cahn, Jr., S. S. Cairns, J. W. Calkin, H. H. Campaigne, R. E. Carr, D. S. Carter, B. H. Colvin, G. B. Dantzig, C. E. Diesen, H. P. Doole, R. D. Dotts, Jim Douglas, Jr., R. C. Douthitt, A. Downing, Worthie Doyle, M. Dresler, C. E. Duncan, H. L. Durham, Jr., L. A. Elrod, M. Elveback, Arthur Erdélyi, Paul Erdös, G. W. Evans, II, J. H. Evans, A. B. Farnell, H. G. Ferris, G. E. Forsythe, F. G. Foster, S. P. Frankel, D. R. Fulkerson, R. S. Gardner, I. M. Garfunkel, Wallace Givens, A. M. Gleason, Max Goldstein, R. A. Good, J. W. Green, H. R. J. Grosch, W. D. Gutshall, D. W. Hall, Cecil Hastings, Jr., R. M. Hayes, M. R. Hestenes, A. J. Hoffman, D. S. Hoffman, J. Hogen, O. H. Hoke, A. S. Householder, M. Howard, L. Hulthen, J. A. Hummel, H. F. Hunter, Rufus Isaacs, Eugene Isaacson, J. S. Isenberg, R. E. Jackson, Fritz John, D. L. Johnson, S. M. Johnson, R. E. Kalaba, William Karush, E. Katz, M. Kennedy, R. E. Kidder, S. I. Klein, Erwin Kleinfeld, H. G. Kolsky, M. Krakowski, Harold W. Kuhn, S. H. Lachenbruch, R. Landshaff, L. R. Langden, J. E. LeBel, R. S. Lehman, D. H. Lehmer, Emma Lehmer, I. J. Lieberman, J. W. Lindsay, H. A. Linstone, B. J. Lockhart, A. T. Lonseth, J. F. Ludloff, J. L. McGregor, F. B. MacKenzie, Irwin Mann, J. Marschak, E. Maso, F. B. Meek, H. H. Meek, W. A. Mersman, H. I. Meyer, C. J. Mifsud, K. L. Miller, E. H. Mookini, A. Moskin, T. S. Motzkin, M. E. Muller, A. B. Neale, A. B. Novikoff, L. J. Paige, Gordon Pall, C. L. Perry, Jr., E. P. Perry, L. L. Philipson, M. Posin, A. G. Prisson, R. Radner, L. Regelson, Edgar Reich, R. R. Reynolds, D. E. Richmond, S. M. Rock, R. M. Roelun, J. H. Rogers, P. C. Rosenbloom, H. D. Ruderman, R. W. Rumsey, Arthur Sard, H. H. Schatz, R. H. Sehnert, J. L. Selfridge, Seymour Sherman, I. M. Singer, Judson C. Smith, S. S. Smith, T. H. Southard, O. S. Spears, K. Spierman, M. L. Stein, M. Steinberg, Robert Steinberg, A. C. Sugar, J. D. Swift, A. H. Taub, Olga Taussky, A. E. Taylor, D. Teichroew, C. J. Thorne, John Todd, C. B. Tompkins, C. H. Tross, J. R. Vine, S. Voris, H. M. Wagner, D. D. Wall, J. L. Walsh, M. Walter, Jack Warga, W. R. Wasow, E. B. Weinberger, R. L. Westhafer, H. W. Wielandt, J. E. Wilkins, Jr., N. Z. Wolfsohn, H. A. Wood, J. L. Wood, Arthur Wouk, J. W. Wrench, Jr., T. T. Wu, D. M. Young, Jr., J. W. T. Youngs.

There were five half-day sessions, at which five hour addresses and sixteen shorter papers were presented. Those presiding at the various sessions were A. M. Gleason, Seymour Sherman, G. B. Dantzig, Fritz John, M. R. Hestenes, and Arthur Erdélyi. One half day was reserved for visits to nearby computing facilities. Visits were arranged to the RAND Corporation, U.C.L.A. Engineering Department, 
Douglas Aircraft Company, Telecomputing Corporation, California Institute of Technology, U.S. Naval Air Missile Test Center, Lockheed Aircraft Corporation, Bendix Computer Division, and the Institute for Numerical Analysis of the National Bureau of Standards.

The following papers were presented, all of which are scheduled to appear in the Proceedings of the Symposium, edited by John Curtiss and published by the McGraw-Hill Book Company. In the absence of Messrs. Bellman, Warschawski, and Fischbach, their papers were presented by Messrs. R. S. Lehman, P. C. Rosenbloom, and D. M. Young, Jr., respectively.

C. B. Tompkins: Application of automatic digital computers to problems with discrete variables.

R. H. Bruck: Computational aspects of certain combinatorial problems.

Olga Taussky: Some computational problems in algebraic number theory.

Emma Lehmer: Number theory on the SWAC.

H. W. Wielandt: Error bounds for eigenvalues of symmetric integral equations.

Wallace Givens: A method of error analysis.

D. M. Young, Jr.: On the solution of linear systems by iteration.

M. R. Hestenes: The conjugate gradient method for linear systems.

Stefan Bergman: Some methods for solutions of boundary value problems of linear partial differential equations.

T. S. Motzkin: The assignment problem.

Richard Bellman: On some computational problems in the theory of dynamic programming.

Harold W. Kuhn: The traveling salesman problem.

S. E. Warschawski: Recent results in numerical methods of conformal mapping.

A. H. Taub: Numerical solution of the equations of pseudo-stationary flow.

J. W. Fischbach: Some applications of gradient methods.

S. P. Frankel: Stability problems in partial differential equations.

J. L. Walsh: Best-approximation polynomials of given degree.

Arthur Sard: Function spaces and approximation.

Cecil Hastings, Jr.: Approximations in numerical analysis.

W. R. Wasow: On the asymptotic transformation of certain probability distributions.

P. C. Rosenbloom: The method of steepest descent.

J. W. Green, D. H. LEHMER

Associate Secretary

Chairman, Arrangements Committee 